States, and, indeed, wherever meteorology is studied. The other subjects treated in these papers include :-

(1) The changes in the hourly variation of the barometer in fine and in cloudy weather at Ben Nevis, Fort William, and several other stations.

(2) The general meteorological conditions on Ben Nevis in clear and in foggy weather.

(3) Atmospheric dust on Ben Nevis.

(4) The pumping effect on a barometer of strong winds.

(5) The difference in the direction of the wind at Ben Nevis from that at sea-level.

(6) The change of temperature with height in anticyclones.

(7) The diurnal ranges of the Ben Nevis and Fort William barometers when both are reduced to sea-level by the usual tables.

(8) The diurnal range of the variability of temperature from day to day at Ben Nevis and some other places.

(9) The meteorological conditions at Ben Nevis during the severe frost of January and February, 1895.

(ı) The relation of wind direction to temperature and to rainfall at Ben Nevis.

The establishment of the Ben Nevis Observatories has provided meteorological data of a character unique in this country, and, indeed, in the world, owing to the position of Ben Nevis as a high-level station placed right in one of the storm-tracks of the Atlantic. But it has also led to investigations which could not otherwise have been carried out, for no increase in the amount or quality of low-level observations would have supplied the necessary data, and the high-level records got from kites or balloons are too fragmentary for the purpose.

The observatories were built with money subscribed by the public, and up to this time have been supported by subscriptions, aided by an annual payment of $100 l$. for the Ben Nevis Observatory and 25ol. for the Fort William Observatory from the Parliamentary grant of $15,300 l$. given annually for meteorological purposes. What their future position may be depends on the recommendations of the Parliamentary Committee of Inquiry into the administration of this grant now sitting, but whether Parliament gives the money necessary to carry them on, or whether they are closed and abandoned, as they assuredly will be if not taken over by the State, the work done at and in connection with these observatories is a record of investigation which will be growingly studied by meteorologists.

Edinburgh, October I7.

R. T. OMOND

No one is more conscious of the shortcomings and omissions of the address than its author. One correction I should like to make here. The joint editors of the Meteorologische Zeitschrift are Dr. Hann and Dr. Hellmann; Dr. Pernter is associated with the journal as "Herausgeber."

I cannot fail to be aware that, with perfect propriety, I might have devoted a large part, or even the whole, of the address to the obligations of meteorology to private enterprise in this country. In that case it would have been a different, perhaps a better, address, but I will ask your readers to believe that any omissions of that kind which they detect and regret were not due to a desire to belittle anything except the address itself.

In one sentence I did explicitly refer to Edinburgh and Ben Nevis. I cannot altogether emulate the achievement of Mr. Puff, who managed to extract so much meaning from a shake of Lord Burleigh's head, but I should like to say that if Sir Arthur Mitchell had used an appropriate magnifying power, and had got it properly focused upon that sentence, he would have read the following opinion which the mention of Ben Nevis always suggests to my mind, "that if means were found for endowing a chair of meteorology in the University of Edinburgh, and one of the distinguished Scottish meteorologists, whose names require no announcement from the chair to make them known to the British Association and far beyond, were appointed thereto, a most important and productive step would be taken towards the solution of the many problems connected with the great Scottish work of the Ben Nevis Observatories, the twenty-first annual report of which Dr. Buchan will present to the Association."

W. N. SHaw. October $2 \mathrm{I}$.

No. 1775 , VOL. 69]

\section{Weather Changes and the Appearance of Scum on} Ponds.

IF any of your readers could explain an interesting natural phenomenon constantly occurring here we should be very grateful. It is simply that, invariably before any decided change of weather, there comes up a scum on the surface of the pool or small lake which skirts our south and east lawns-part of the pleasure grounds surrounding the mansion. Sometimes it looks like soapy water, but at other times it is black, and makes the breasts of our swans as black as ink just above the water-line. Then the scum will suddenly disappear, and the swans' breasts become white again. Our geological formation is the junction of the Upper Greensand and the Lower Chalk. The bottom of our lake is chalk; it is fed by springs, and the stream formed by its overflow runs finally into the Thames. It is shallow, and is surrounded by large trees. There are at present eight swans on it, also many moorhens and wild duck, and quantities of fish, which attract herons; kingfishers live in the bank, which is very high on the far side. There is also an island with large trees and a dense undergrowth.

Aston Rowant, Oxon.

WiTh reference to the letter of "Platanus orientalis," it seems to me that a possible explanation of the appearance of dirty scum on the surface of the pond before any decided change of weather may be that a sudden change of barometric pressure may accelerate the flow of springs rising through the chalk of the floor of the pond. This would carry up to the surface of the water some of the fine mud which had rested on the chalk, or even lodged in crevices within it. When the flow of the springs diminished or ceased, the sediment would naturally subside once more. It would be interesting to keep an exact record of the appearance of the scum and of the variations of atmospheric temperature, pressure, and the rainfall by automatic recording instruments.

Without knowing the local conditions it would be impossible to speak definitely as to the sufficiency of this explanation.

Another that occurs to me is that, if the sediment at the bottom of the pond is of a flocculent character, its movements may be due to the same cause as those of the precipitate in a "storm-glass," whatever that cause may be ; but in that case the appearance would probably be limited to dead calm weather.

It is possible that the scum may be organic, and it would be desirable to have it examined microscopically by a student of limno-plankton.

\section{Hugh Róbert Mill.}

\section{Cranial Casts.}

IN the number of NATURE which arrived here to-day there is a report of the interesting presidential address delivered by Prof. Symington in Section $\mathrm{H}$ at the British Association's recent meeting. In this report there are several statements which are likely to prove misleading to those who are not familiar with the literature relating to brain-casts. The reader might imagine (see p. 540) that this was an entirely new branch of research suggested by Dr. Forsyth Major's work on the subfossil Lemuroids ( 1898 ) and only fully exploited by Prof. Schwalbe in 1902. This, of course, cannot be the meaning which Prof. Symington intended to convey, because he is quite familiar with the scores of cranial casts made in such profusion by Prof. Gervais in the years $1867-1871$, and by a long line of anatomists and palæontologists both before and since that time, and with the valuable contributions to knowledge which have resulted from this fertile branch of study; in fact, Prof. Symington happened to visit the work-room in the Royal College of Surgeons in I9OI when I was examining and describing the considerable collection of such casts (representing more than one hundred genera) which have been brought together by the late Sir William Flower and the present conservator, Prof. C. Stewart. (And, with reference to Prof. Symington's remarks on curators, I may mention that no one more fully recognises the value of cranial casts than the present conservator of the Royal College of Surgeons' Museum.) 